\title{
HISTORICAL CHANGES IN DISPERSED KOPANITSE LAND TYPE AND CHANGES IN USE OF AGRICULTURAL LAND ON KYSUCE REGION EXAMPLE
}

\author{
PETER BARANČOK, MÁRIA BARANČOKOVÁ
}

Institute of Landscape Ecology, Slovak Academy of Sciences, Štefánikova 3, P.O. Box 254, 81499 Bratislava, Slovak Republic; e-mail: peter.barancok@savba.sk, maria.barancokova@savba.sk

\begin{abstract}
Barančok P., Barančoková M.: Historical changes in dispersed kopanitse land type and changes in use of agricultural land on Kysuce region example. Ekológia (Bratislava), Vol. 35, No. 4, p. 371-391, 2016.

Territory of Kysuce is characterised by a high proportion of the traditional agricultural landscape (TAL), which occupy almost $12 \%$ of the area. Two types of TAL were allocated here. The first type is represented by TAL with dispersed settlement. The second type is represented by TAL of arable land and grassland landscape. The largest representation has typical forms of anthropogenic relief (FAR). TALs represent the most diverse mosaic of man-made habitats and natural habitats too. In the past, there were the largest representations of arable land and regularly mown meadows. Currently, these areas are dominated by abandoned meadows (fallow meadows), occasionally grazed pastures and meadows. Arable land is represented only minimally. The large part of areas is overgrown by non-forest woody vegetation or passes to the forest vegetation. In this process of landscape changes, significant changes in biodiversity of the areas are realised. Successively, the species of segetal and ruderal vegetation are less represented and species of forest vegetation obtained greater representation. In the process of mapping and evaluation, FAR - shape and orientation of plots, types of balks and some of their basic characteristics - were monitored.
\end{abstract}

Key words: forms of anthropogenic relief (FAR), landscape changes, landuse, traditional agricultural landscape (TAL).

\section{Introduction}

Dispersed settlements in each municipality consist of two basic components: the village centre and land outside the village centre with dispersed houses. Both of these components are housing estates, having a mutual bond in the sense that the head of the village centre is usually the centre of gravity of all hamlet lands. Today, dispersed settlements are connected by road to a central village, which supplies them with essential services and requirements. Up to now, these landscapes, with parts of the dispersed settlements of the sub-mountain region, reflected the face of the landscape, its history and folklore (Špulerová et al., 2014; Sitár, 1967). Five main areas of dispersed settlement are allocated in Slovakia, which are divided into sub-areas. Kysuce region belong to dispersed settlement of the Javorníky Mts and the Beskydy Mts. 
Establishment of dispersed settlements in Slovakia is related to waves of colonisation from the 12th to 19th centuries. In the past, a dominant part of Kysuce region was covered by forests. The large growth in population has caused the clearing of large forest complexes and the formation of pastures and meadows, part of which was converted into the fertilised arable lands during the next periods. The first settlers had acquired the land necessary for the construction of their dwellings and for agricultural purposes by clearing and burning of the forest. The techniques of land acquisitions have been developed over a long period of colonisation process, and specifically, as to the colonisation of the Kysuce region, these techniques did not exhibit any distinct characteristics. They were mainly used during the early period of Wallachian colonisation, in the 'Kopaničiarska' colonisation, in the process of maintaining of grasslands and pastures, and they persisted even during the first half of the 20th century. The fields on steep terrains were located along the contour line and in a terraced way so as to prevent any washing off of arable land at the time of rains and spring snowmelt. As a result of this specific cultivation of land that took place during a period of hundreds of years high field margins that provided the most effective anti-erosion protection of fields in these climatic conditions have been created.

The colonisation of Kysuce region (Tóthová et al., 1996) took place in the 14th and early 15 th century. The colonisation continued in slow progress, and in the early 15 th century, only lower Kysuce up to Krasno nad Kysucou town and Kysucký Lieskovec village were inhabited. The upper Kysuce was unpopulated even at the end of the 15th century. At the turn of the 16th century, Wallachian ethnicity begun to emerge in the vicinity of Kysuce region. Wallachian shepherds had hewn relatively large areas of forests and turned them into grasslands and pastures, and then they started to economically use these lands with the flocks of mountain cattle. The main occupation of Wallachian shepherds was mountain shepherding and breeding of cattle, sheep and goats in the isolated areas around their chalets, as well as the craftsmanship of the products of their livestock. In the second half of the 16th century, the forest and grasslands areas were converted into clearing areas, where the Wallachian population begins to grow agricultural products.

The collectivisation fundamentally changed the overall character of rural areas. There was a politically driven process, based on the socialist idea of common property that should be for the benefit of all working people equally (Swinnen, 1999; Palang, 2010; Baran-Zgłobicka, Zgłobicki, 2012). The aim of the collectivisation was to minimie the private property and to consolidate all agricultural land to large-scale fields suitable for industrial agriculture. Central and Eastern European countries followed the Soviet example. The collectivisation was not just a technical adjustment but a profound and traumatic event at social level (Morell, 2012) and also a powerful driver of landscape change (Lipský, 1995; Kristiánová, Adamková, 2010). The resulting changes have included the concomitant and opposing processes of intensification and land abandonment (Plieninger et al., 2006). The collectivisation and central planning (by the year 1949), change from central to market economy (1950-1989) and accession of Slovakia to EU (after the year 2004) are basic policy-induced milestones of the agricultural change following World War II in Slovakia (Izakovičová et al., 2008; Bezák, Mitchley, 2014; Kanianska et al., 2014). Agricultural policy can be identified as key generic driving force that has changed farming management. During the collectivisation of agri- 
culture, large collective and state farms were formed in the 1950s and 1960s. In mountain regions, this process occurred at a later stage, the beginning of the 1970s. During collectivisation (1970-1989), large-scale production was improved and agricultural farms were further merged. Agricultural activities such as grazing were carried out on steep slopes and other inappropriate localities resulting in soil erosion and land slips. Technological developments allowed the widespread use of heavy machinery and application of fertilisers and pesticides in areas that had previously escaped such treatments (Turnock, 2002; Olschofsky et al., 2006). The combined impact of these transformations resulted in a completely new landscape pattern in almost all mountain regions bringing significant ecological consequences.

Ongoing trends in agricultural decline have negative impacts on biodiversity in Central and East European countries (Young et al., 2007) and specially on mountain biodiversity and the rural landscape across Europe (MacDonald et al., 2000; Price, 2006; Reed et al., 2009; Spehn et al., 2006). Mountain areas are hot spots of biodiversity, and agriculture has played a multifunctional role in defining and sustaining mountain biodiversity and maintaining rural livelihoods (Mitchley et al., 2006). Europe's mountains cover nearly half of the land area and are home to one-fifth of the European population (Price, 2006).

Traditional agricultural landscapes (TAL) with dispersed settlement are distributed mostly in mountainous areas. They are composed of dispersed settlement buildings and agricultural plots, that is, arable land, grasslands, orchards and so on. Collectivisation in agriculture changed the landscape character in many regions with dispersed settlement (Petrovič, 2006). Many agricultural mosaics were merged into large-block fields and the elimination of private cattle and sheep breeding caused abandonment of grasslands. Relationships between human and the agricultural land were interrupted and changes in employment structure and a decrease in local residents led to a decrease in traditional management of TAL with dispersed settlement. The Kysuce region has a very important status within Slovakia as regards the TALs because of its geographical location, natural conditions, historical development, type of settlements and human utilisation of the land (Barančok, Barančoková, 2016). Historical structures are slowly disappearing with buildings being eventually transformed into recreational houses. The main object of our interest was the assessment of changes in the landscape structure based on indices from land use interpretation at different time horizons, typically from the Wallachian colonisation, through the collectivisation till the present and the presence of the forms of anthropogenic relief (FAR) in the TAL sites. We monitored the shape and orientation of plots, types of balks and some of their basic characteristics such as length, width, height, skeleton and coherence. Special attention was paid to study the habitat diversity of FAR (including their species composition).

\section{Material and methods}

Our results are based on an interdisciplinary approach to this research and included data, results and analyses from ecological surveys and analysis from socio-economic assessment. Integration was processed by using geographical information systems (ArcGIS 10.0 software) to present results at the landscape level and to allow comparison between different regions. Historical data on the distribution of agricultural land were taken from Tóthová et al. (1996), Demo et al. (2001), statistical yearbooks of land resources (1980) and DATAcube of Statistical Office of the Slovak Republic (1996-2014). A key point was the assessment of changes in the landscape structure based on the 
indices from land use interpretation at different time horizons, typically from the Wallachian colonisation, through the collectivisation till the present.

TAL are characterised by small-scale structure of plot division and by unchanged ways of land use during socialistic collectivisation, or by preserved forms of anthropogenic relief or by preserved features of traditional agricultural technologies. The methodology of TAL mapping was published in Dobrovodská et al. (2010) and Špulerová et al. (2011). The preserved TALs in the Kysuce region were mapped using a combined method comprising visual interpretation of aerial photos and field surveys (Barančok, Barančoková, 2016).

Forms of anthropogenic relief in the TAL sites were mapped and classified in terms of nationwide classification (Dobrovodská et al., 2010). The shape and orientation of plots, types of balks and some of their basic characteristics such as length, width, height, skeleton and coherence were monitored. In the methodology of mapping of TAL, three types of plots in terms of their shape were determined - narrow-band plots, regular quadrangle plots and differently shaped plots.

The phytosociological relevés were assessed and compared with the data obtained from surrounding biotopes and tested on their possible relation to some of the biotopes of European or national significance (Ružičková et al., 1996; Stanová, Valachovič, 2002) in relation to possible proposals on legislative protection of TAL or of biodiversity in individual FAR.

\section{Study area}

The Kysuce region is located in the north part of Slovakia, and from the orographic view, it covers a part of the Slovak-Moravian Carpathians, Western Beskids and Middle Beskids. In the west, it is limited by the state borders with the Czech Republic that run along the ridge of Javorníky Mts. and Turzovská vrchovina Mts. In the northwest, the region's borders pass alongside the Moravsko-Sliezske Beskydy Mts. and Jablunkovské medzihorie Mts. In the northeast, the Kysuce region neighbours with Poland, whilst the borders pass along the ridge of the Kysucké Beskydy Mts. In the east, the borders of the region reach the eastern edge of Kysucká vrchovina Mts., which together with the Kysucká brána Gate also form the southern border of its territory. Southwestern part of Kysuce region is represented by Javorníky Mts.

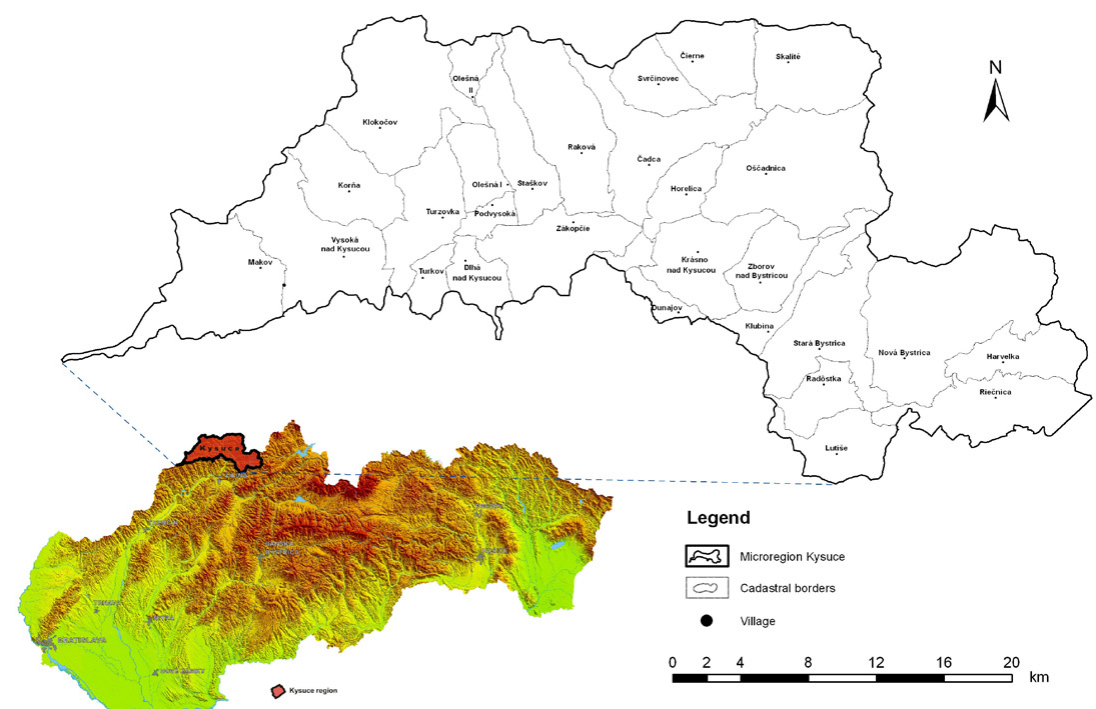

Fig. 1. Localisation of study site. 
This region was determined on the basis of natural-residential types of regions of Slovakia (Miklós, 2002). It consists of 24 municipalities, 23 of which belong to the district of Čadca town - Čadca, Čierne, Dlhá nad Kysucou, Dunajov, Klokočov, Klubina, Korňa, Krásno nad Kysucou, Makov, Nová Bystrica, Olešná, Oščadnica, Podvysoká, Radôstka, Raková, Skalité, Stará Bystrica, Staškov, Svrčinovec, Turzovka, Vysoká nad Kysucou, Zákopčie, Zborov nad Bystricou and one municipality belongs to the district of Žilina city - Lutiše. Čadca town includes two cadastral areas - cadastral areas of Čadca and Horelica; Turzovka village also includes two cadastral areas - cadastral areas of Turzovka and Turkov; cadastral area of Olešná village consists of two separated units - cadastral area of Olešná I and Olešná II; Nová Bystrica village from the date of the construction of water reservoir 'Nová Bystrica' includes three cadastral areas - cadastral areas of Nová Bystrica, Harvelka and Riečnica. The monitored territory of Kysuce region represents 29 cadastral areas (Fig. 1).

\section{Results and discussion}

Changes in the representation in elements of TAL and biodiversity from the historical point of view

Kysuce region started to change more intensively during the period of the first colonisation Wallachian colonisation - dated to the 14th and the beginning of the 15th century, upper Kysuce were colonised towards the end of the 15th century. In this period, people settled mainly in valley localities and former wood and marshy communities near bigger watercourses were gradually transformed into meadows and pastures and later, approximately in the second half of the 16th century, into arable land. It is supposed that during this period, lower parts of the slopes were altered and first terraced plots appeared. Placing of plots on slopes was important for their further position from the reach of water from streams and rivers that raise their level during snowmelt in spring. The first significant change thus brought reduction in forest areas, expanding of grassland communities used as pastures and meadows and first bigger arable lands and terraced plots emerge (Fig. 2).

It can be estimated that overall qualitative species diversity of the region has not changed (or not significantly), as at that time a big migration of the population amongst various regions had not yet occurred and neither had any new plant species been introduced into the region, be it on purpose or by accident. However, there have been some quantitative changes. Forest species have been pushed away from the settled areas and substituted by species bound to more sunlit areas and species of grassland vegetation characteristic for meadows and pastures, and nitrophilous vegetation can be seen on more nutrition-rich areas influenced mainly by the presence of farm animals.

Major changes in the landscape structure and land use occurred in the period of kopanitse colonisation that had started even before the end of the 16th century and continued until the beginning of the 20th century. In this period, the whole Kysuce region was colonised and almost all today's scattered 'kopanitse' settlements were established. Kopanitse colonisation is connected with the cultivation of land with shepherd's huts when temporary dwellings become permanent ones. Some 'kopanitse' were gradually transformed into bigger settlements and even villages. In this period, the biggest decrease in forest areas took place, which transformed into meadow and pastures, and at the same time, kopanitse colonisation on a wider scale brings along also the cultivation of barren land on foothill and mountainous areas (Fig. 2). In this period, almost all today's TAL areas emerge and all were actively cultivated. 
Apart from the significant changes in the landscape structure, changes in the proportion of natural to man-made elements or natural to man-conditioned biotopes (types of vegetation) can be observed as well. Apart from the reduction of the area occupied by forests, the change was also visible in the species present in the areas. Instead of mixed beech, fir and spruce forests, spruce forests become the dominant ones. Thus plant species spectrum in the undergrowth changes as well. With regards to intensive utilisation of valley positions near watercourses and quite substantial movement of farm animals in the region, other types of natural non-woody vegetations bound to wetlands, spring areas, raised bogs and so on are gradually disturbed and destroyed as well. Grassland population of meadows and pastures character found in valley and ridge positions become dominant and are intensively used in the whole monitored region.

Simultaneously, movement of larger groups of inhabitants within the given region and amongst the neighbouring regions occurs, be it to the south to towns in Považie region (Kysuce was a part of Trenčín county) or to the north to Polish regions. Movement of the inhabitants was connected with natural migration of population and trade. Mainly with agricultural products (plant and animal) coming into the territory of the new types of plants characteristic for the southern areas appear - especially the types of ruderal and segetal vegetation. Deforestation of the region, especially in valley position, brought change in microclimate and slight warming, which simultaneously enabled better conditions for natural spreading of

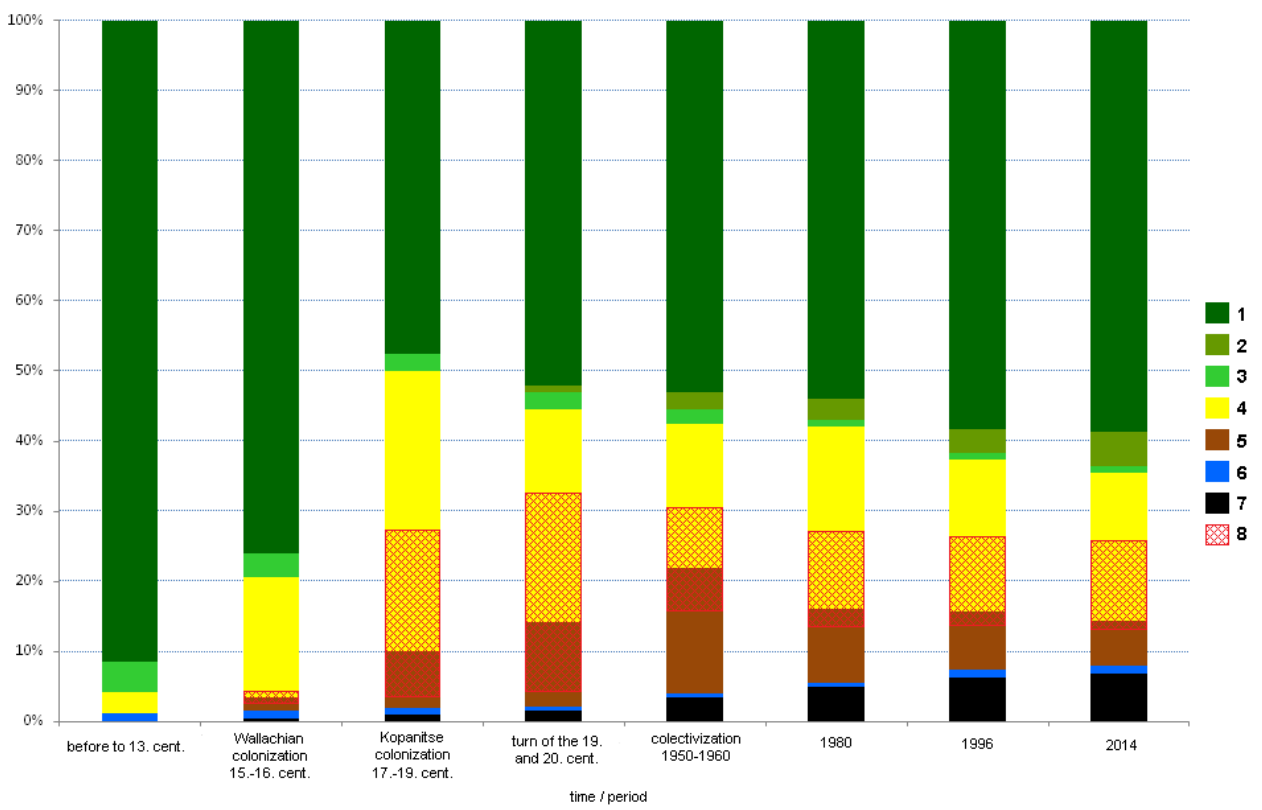

Fig. 2. Representation of the basic types of landscape structure and TAL elements on the monitored Kysuce region in different historical periods.

Notes: 1 - forest; 2 - non-forest woody vegetation; 3 - natural non-forest grassland vegetation; 4 - meadow and pastures; 5 - arable land (including gardens, orchards, etc.); 6 - watercourses and water surfaces; 7 - built up areas; 8 - TAL. 
thermophilous species from the south to 'open' areas. It had a positive effect on the character of meadows and pastures and the quality of grassland stands with regards to the production.

In the second half of the 19th century, intensive clear-cutting of forests ceased, and approximately from then on, the reduction of their size stopped as well. Several important legal norms concerning the cultivation of land were connected to this. The most significant legal norm was Hungarian forest law or the Act number XXXI from 1879, active until 1960. The law obliged each and every owner of forest land to use the land in compliance with the forest cultivation plan.

Representation and use of grassland stands were stabilised, partially with the rising population the proportion of arable land used for agriculture was raising as well. It can be stated that in this period, in Kysuce region, the biggest proportion of the land was TAL from which the arable land was the dominant element (Fig. 2).

Breakthrough period in the way of utilisation of agricultural land, with regards to TAL existence, was the period of collectivisation of agriculture (collectivisation) in the 1950s and 1960s of the 20th century when individual private land became state owned. State agricultural companies or cooperatives emerged, and unification of plots took place in the whole Kysuce region. More than a half (maybe even two-thirds) of small TAL plots were ploughed and former terraces and field margins were destroyed, and individual plots were joined into big stretches. Big areas of arable land were formed, and arable land was highly represented at that time. With regards to climatic conditions, several areas of arable land and possibilities of cultivation of agriculture were gradually transformed into large-scale recultivated highproduction grasslands and agriculture focused on animal production once again.

The individual TAL elements on smaller or bigger areas were preserved only either in the vicinity of settlements on steeper slopes, less accessible to agricultural machinery, or on relatively smaller areas less suitable for large-scale utilisation. This TAL structure has been more or less preserved until today (Fig. 2).

These changes have influenced not only the land structure and the representation of TAL elements but also the biodiversity of the region. The existing mosaic of land elements that served as an important site, food, shelter and so on basis for the existence of a great number of plant and animal species got lost on big areas. Ploughing of the fields often affected other non-woody biotopes, site conditions for their existence were physically destroyed or were changed by ameliorating processes. Large-scale fields, utilisation of artificial fertilisers and pesticides, recultivated grasslands with only several species of grass, clover, alfalfa and so on did not provide such variability of site conditions to sustain former species and biotope variability.

In this period, remote areas cease to be used for agricultural purposes and interest of independent farmers in them decreases as well. Thus, forest areas expand either by targeted re-forestation by favouring spruce (Picea abies) or by self-rejuvenation. That is why elements of non-forest woody vegetation (NFWV) have higher representation.

In the second half of the 20th century, especially towards its end, population concentrated in individual settlements gradually raises, leading to the increasing proportion of built-up areas in the region. This trend came to an end at the turn of the 20th and 21st centuries, and nowadays, it is in decline. 
Towards the end of the 20th century representation of arable land in the region decreases and a great part of grasslands and pastures cease to be intensively used or only smaller areas in lower parts of hills are used. Little by little, TAL areas are abandoned.

Nowadays, new changes in utilisation of the region occur, which negatively affect TAL existence. It is mainly abandoning of traditional ways of agriculture in the region. Individual terraces are no longer used as arable land, and either wasteland is created, or grassland stands are mown, or cattle are tended there. Later, the areas are abandoned in general and are taken over by wood vegetation. One part of terraced plots in the higher elevations was re-forested and another part in the lower elevations is built-up.

With regards to the land diversity, these current changes can be seen as negative where traditional elements of land structure are gradually lost. Assessment of these changes with regards to the diversity is more complicated and needs to be approached from several angles:

1. Increase in representation of forest area can be assessed positively, but the question of their 'quality' is more complicated - species representation of forest floor is still dominated by spruce (spruce monocultures), which is reflected in their damage by wind calamities, subsequent infestation of bark beetle insects and bad health condition. Higher forest areas are included in the statistics, but areas of calamity sites and clear-cut areas are included.

2. Portion of NFWV is increased by the overgrowth of abandoned meadow and pastures. These growths in gradual process of natural succession lead to forest areas that, with contrast to planted forests, have natural species structure; deciduous trees are highly represented; and the undergrowth is composed of mixed forest species with former grassland stands. Quite a great number of animal species is bound to these temporary populations, and thus with regards to overall biodiversity of the region, they can be assessed very positively.

3. Natural grassland vegetation - wetlands, water surfaces with water vegetation, peat bogs, raised bogs and so on - have lower representation in the region that is the result of all past and present historical changes and ways of utilisation of the region. Big part of this vegetation was physically destroyed in the past, and with regards to changed site conditions, it cannot be renewed even after abandoning of agricultural utilisation of the areas.

4. Great changes also occur in the composition of the species and state of meadows and pastures. Meadows and pastures represent 'agricultural type of vegetation' and their state and composition of species is bound not only to site conditions but also to the way and degree of utilisation. Former areas were mostly various in species and consisted of native species of grass and herbs. In the process of intensification of agriculture, a great part of grasslands and pastures was recultivated and transformed into highly productive areas with three to five dominant grass species with high production of biomass and in the undergrowth could be found mainly cross-bred forms of clover and other forage crops. From the former flora, there are very little species. Although such areas were agriculturally important, they are very poor as to biodiversity. Nowadays, a great part of these areas is unused and thus they lose their productive significance and return to original colourful meadows is almost impossible without human interference (it is more likely that through the process of succession, wood areas are going to be renewed). 
5. After the period of collectivisation and intensification of agriculture, original colourful meadows and pastures were preserved mainly on margins of agriculturally utilized slopes, mainly in higher elevation areas and on extreme slopes. One part of them created bigger areas and the other created on TAL elements. In these growths, higher species diversity was preserved. In recent years, it was these growths that were abandoned as first, and a part of them has been taken over naturally by woody vegetation.

6. As meadows and pastures in Kysuce region are the second most important and expanded type of vegetation after forests, negative changes exhibited on their state and following development affect negatively the overall biodiversity of the region.

7. In recent years, representation of arable land has been on decline on the monitored region. For example, whilst on 1980 in the original Čadca region, there were 9,254 ha of arable land, in 2014, there were only 4,959 ha. This statistics is processed based on the data from cadastre of immovable property and DATAcube of the Statistics Office of SR. By experience gathered from field study, it can be stated that the surface area of really used land such as arable land is significantly smaller. Thus, plant and animal species bound to such biotopes are less represented, segetal vegetation is less represented and ruderal vegetation of wasteland and abandoned areas become dominant. Gradually woody vegetation is becoming more prevalent. And species of synanthropic vegetation can be found in its undergrowth.

8. Similar problems can also be found in other types of vegetation, but for their lesser connection to TAL elements, they will not be mentioned into detail in this article.

All changes in landscape structure and in utilisation of individual elements of the landscape are reflected also in composition of communities of these sites that will subsequently show on changes in biodiversity of the whole monitored region.

\section{Forms of anthropogenic relief (FAR)}

Amongst the basic parameters that were monitored in the process of mapping and the evaluation of FAR were the shape and orientation of plots, types of field margins and some of their basic characteristics such as length, width, height, skeleton and coherence. The type of vegetation on these FAR was also evaluated.

In the methodology of mapping of TAL, three types of plots in terms of their shape were determined - narrow-band plots, regular quadrangle plots and differently shaped plots.

In the territory of Kysuce region, the narrow-band plots (Figs 3, 5, 6, 8, 9) have the absolute predominance, which is mainly due to the shape of the relief, because there is a significantly rugged terrain with steep to moderately steep slopes, but the formation of these forms was also affected by the rocky environment with a predominance of less stable flysch rocks and by climatic conditions, especially large amounts of precipitation. These conditions prescribed the land use for the primary farming of the areas, which caused the formation of the characteristic forms of TAL. In the whole region, a multi-interlinked system of narrow terraces was created; this system is less burdensome to the slope and more resistant to landslides and erosion, and it also prevents the floating away of the upper parts of the soil during the rainy season. And of course the straighter terraces are also easier to cultivate (farm). Narrow- 


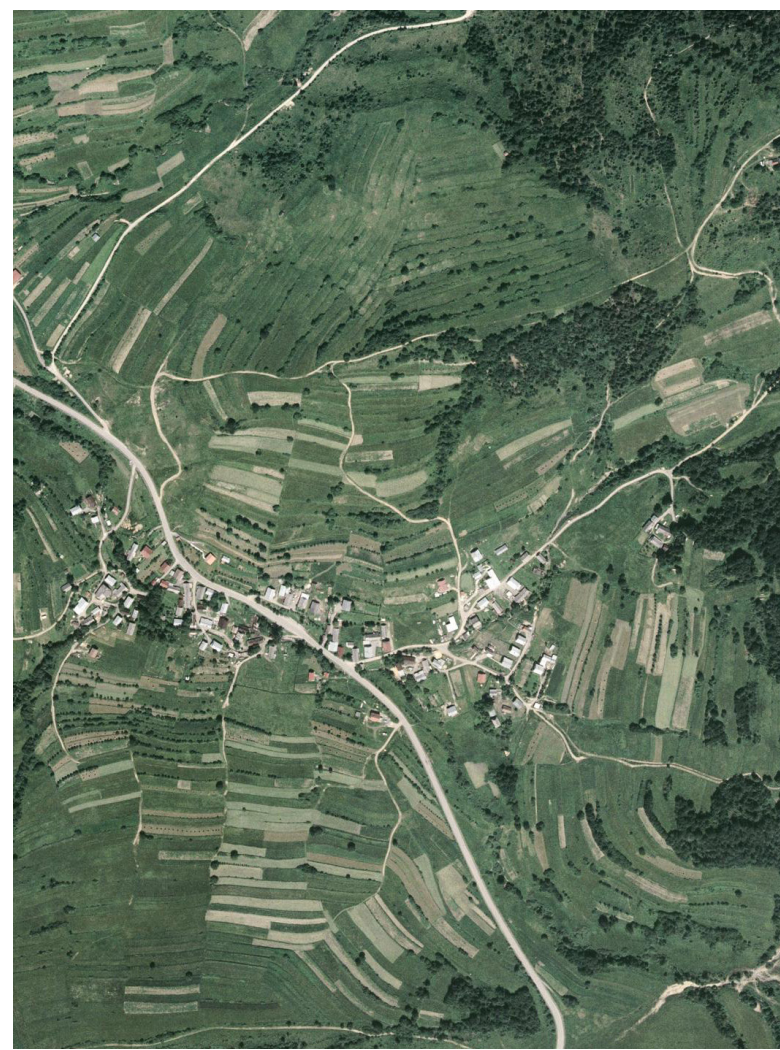

Fig. 3. Narrow-band plots in Lutiše village. band plots cover 2,608 ha, and areas with dominant narrowband plots cover 6,234 ha.

The width of the terraces in most cases is directly conditioned on the slope inclination, that is, on steeper slopes, there are narrower plots and on the less steep slopes, the plots are wider. Simultaneously, the width of plots (i.e. of terraces) was conditioned upon their purpose. Where they have been used as permanent grassland stands (PGS), or they were used for the cultivation of less demanding grains, such as oats or crops for animal feeding, these plots could be less aligned and thus could also be wider. However, if they were intended for regular cultivation of root crops, the plots had to be straighter and narrower. Therefore, an entire system of passages has been formed here, for example, from the typical

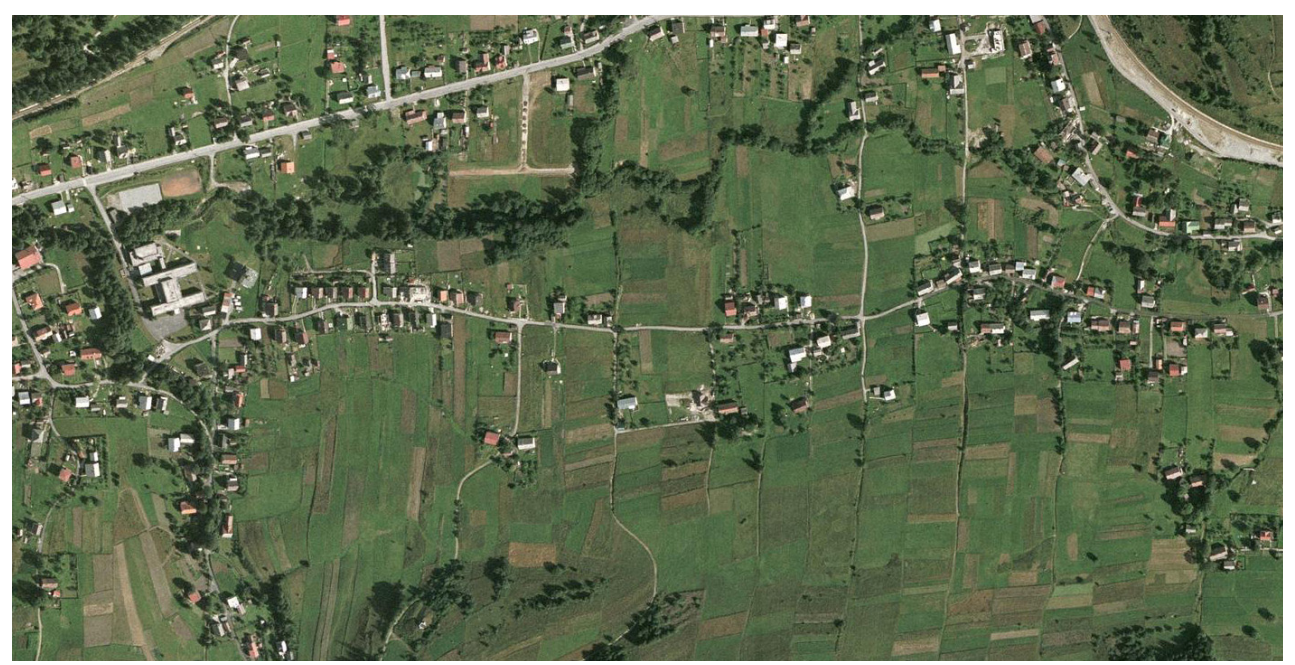

Fig. 4. Quadrangle plots in Skalité village. 


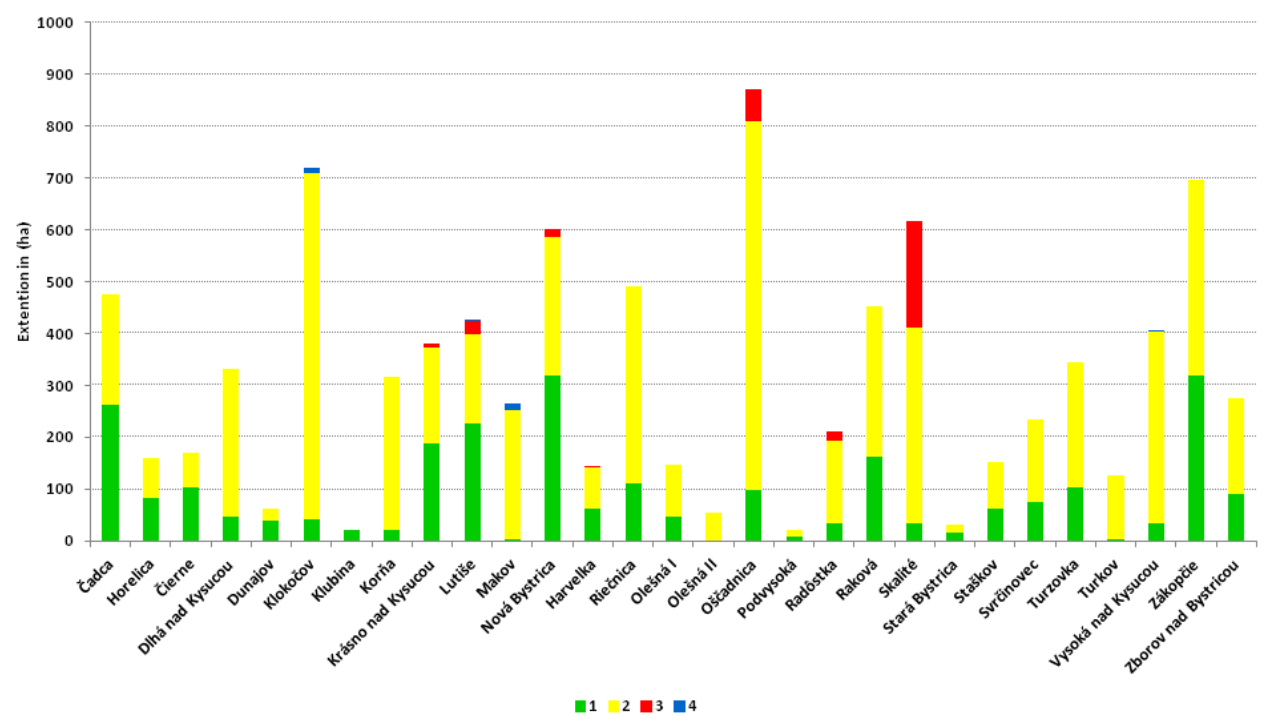

Fig. 5. Extention of plots in the Kysuce cadasters.

Notes: 1 - narrow-band plots; 2 - dominant narrow-band plots and less of the other plots; 3 - quadrangle plots; 4 - differently shaped plots.

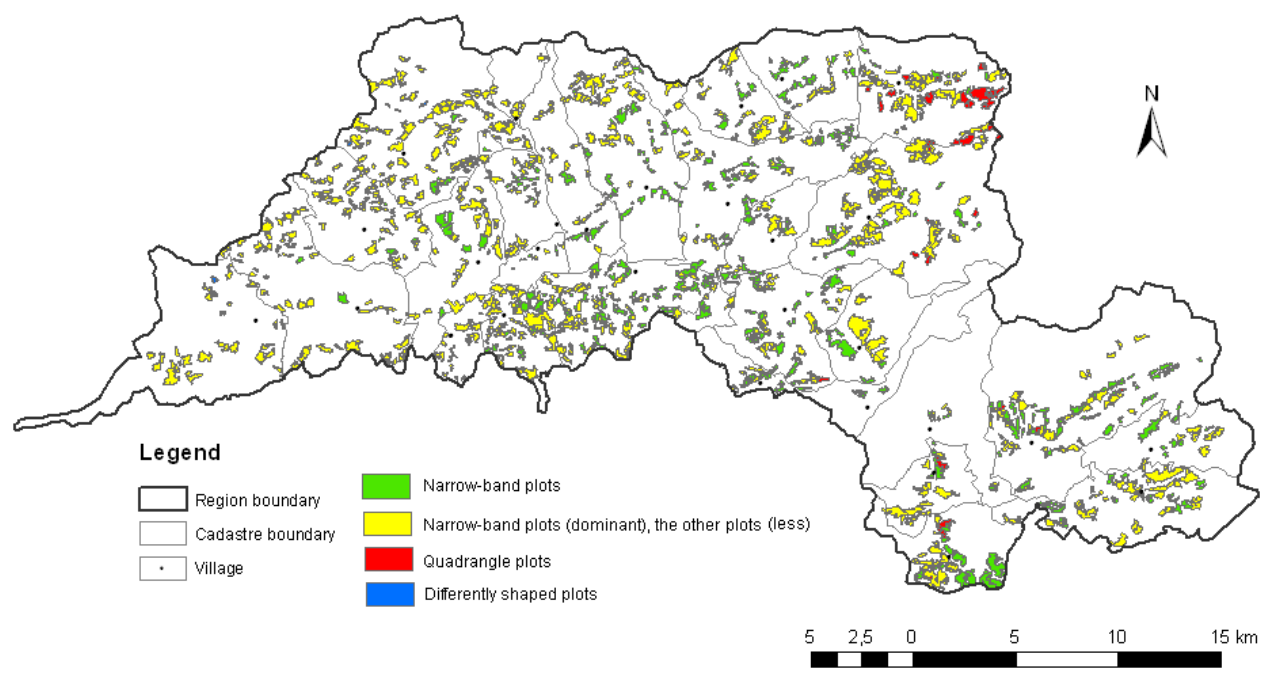

Fig. 6. Shapes of plots in the areas of TAL. 
narrow-band plots with the width reaching about $3 \mathrm{~m}$ (sometimes less) up to plots with width of 15-20 m (sometimes more) and in which case we could be talking about wide-band plots. The narrow-band character of plots is often given because of the total length of plots, where in some cases, it often reaches 120-200 $\mathrm{m}$ (and there were even reported longer plots). The wider plots within mosaics were in such cases characterised within the mapping of TAL as plots of another shape.

Regular quadrangle plots (Figs 4-6) are not widely spread in Kysuce region (335 ha of area), and they originated on the less steep slopes, where the wide-band plots were divided by several access roads and footpaths leading directly into the slope and perpendicularly to the terraces. Exceptions are fairly regular plots in the northeastern part of the monitored territory in the cadastral areas of Skalité village, Čierne village and in some parts of the cadastral area of Oščadnica village (e.g. in the community Vreščovka), where these regular quadrangle plots represent a dominant form of plots.

Regular quadrangle plots are mostly represented in the eastern part of the cadastral areas of Zborov nad Bystricou, Nová Bystrica, Radôstka and Lutiše villages, where they create various mosaics with narrow-band plots and their incidence is mainly conditioned on the shape of the relief.

The category of differently shaped plots usually consists of wide-band plots as well as plots of different shapes found mainly in the vicinity of buildings within dispersed settlements, which were cultivated in various manners depending on the construction of houses and adjustment of their surroundings. And in this category, there were also included occasionally occurring plots of larger dimensions if they were part of a larger complex of narrowband or quadrangle plots (28 ha of area).

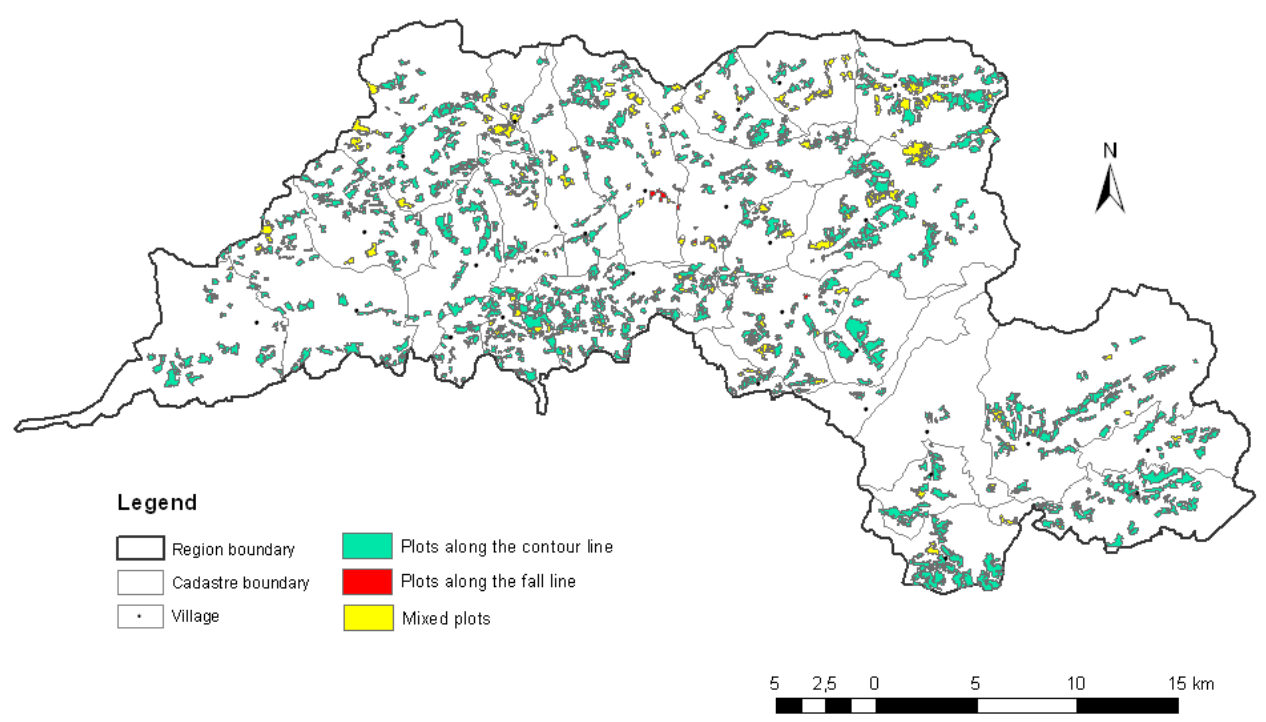

Fig. 7. Shapes of plots to relation relief. 
Throughout the monitored territory, regardless of the shape of the plots and giving consideration to the relation of plots to relief, the most dominant plots are plots spread along the contour line (Fig. 7) $(7,864$ ha of area), which only sometimes slightly descend or ascend with respect to the overall configuration of the terrain. Less common are cases where the inclination of plots is more tilted to the fall line or where there is a combination of plots spread along the contour line and the fall line. Those are mainly the plots found on the slopes with a slight inclination at lower elevations or plots spread over slightly waved slopes. Such cases were evaluated as a mixed course of plots (1,371 ha of area). Only very rarely, there have been plots spread mostly along the fall line (31 ha of area) and only in the lowest positions of slopes, where these plots continuously follow or pass to the small yards located mainly on the flood plains of the individual watercourses.

In the process of cultivation of steeper slopes because of the nature of the relief, the terraces were mostly

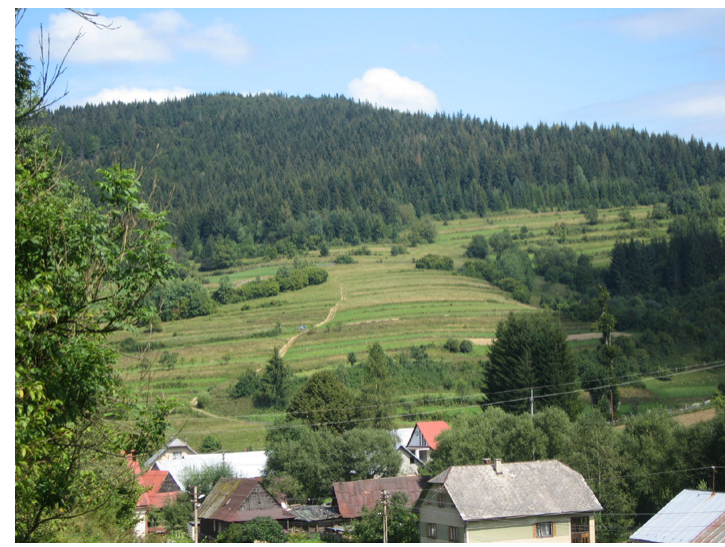

Fig. 8. Grassy terraces (Lutiše village).

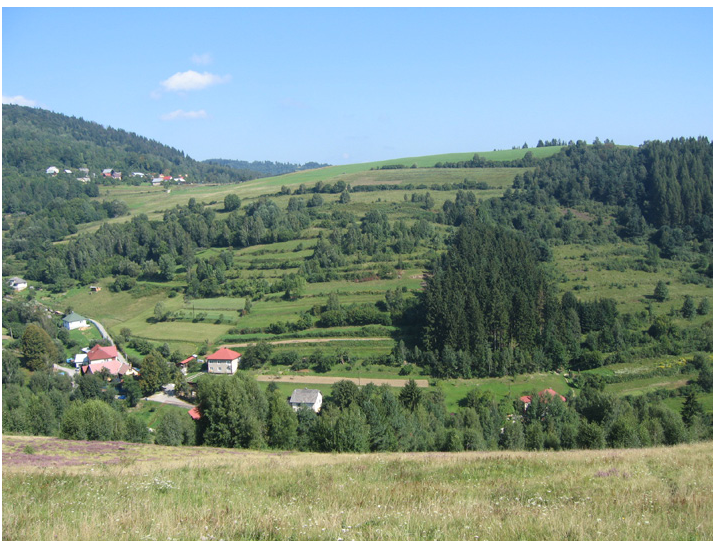

Fig. 9. Terraces with non-forest woody vegetation (Krásno nad Kysucou village). formed; these can be located almost throughout the entire monitored territory. The size of the individual terraces corresponds to the above described size of plots. The balks of these terraces are usually 1-2 $\mathrm{m}$ high (rarely below $0.5-1 \mathrm{~m}$; occasionally higher than $2 \mathrm{~m}$ ), their width is $1-3 \mathrm{~m}$ (depending on the height) and their length corresponds to the total length of plots, because these field margins are almost always connected and they end where the plot ends.

In terms of skeleton content, the most widespread balks are sandy loam-rocky balks, whilst sandy loam or rocky clay balks are less common. The vegetation coverage of field margins depends on the nature of the terraces use and on the intensity of their use. When the terraces are used as arable land, the balks are dominated by ruderal grassy vegetation with mostly nitrophilous species of plant and the representation of individual species varies depending on whether they are mowed or not. When the terraces are used as PGS on long-term basis, the vegetation coverage of balks s is similar to the PGS, and depending on whether they are 


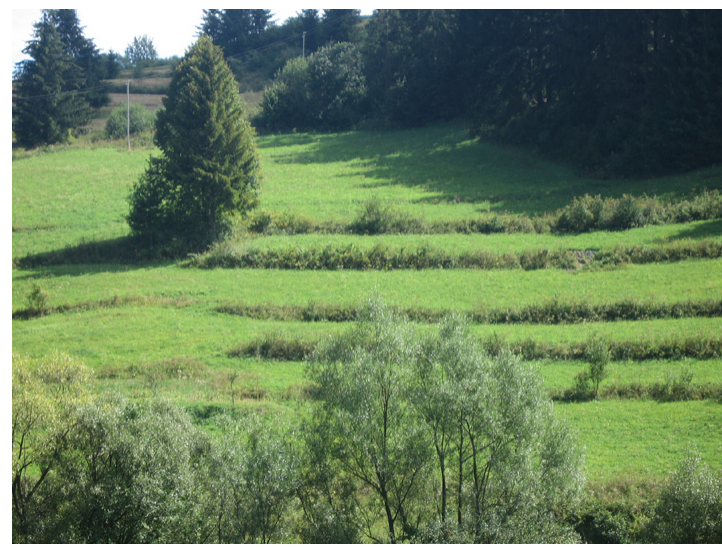

Fig. 10. Step balks (Lutiše village).

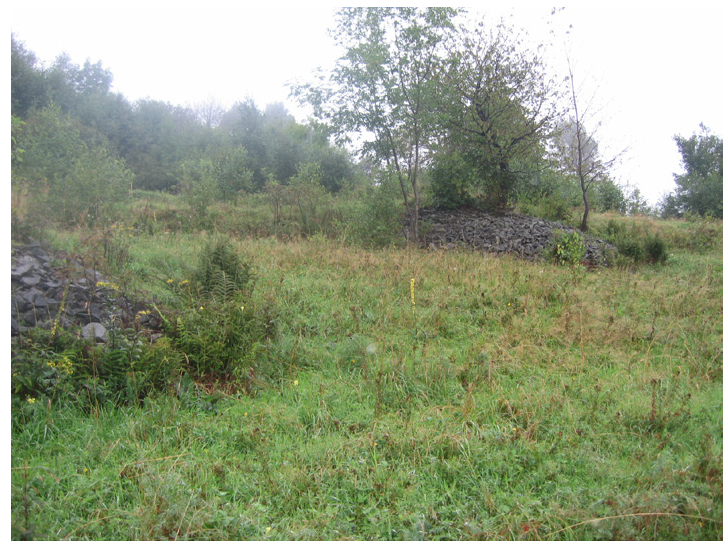

Fig. 11. Heaps (Oščadnica village). mowed or not, they are dominated by grasses or by other species characteristic for unused PGS. Balks are also those places where bushes and trees are first spread in the process of overgrowing of the terraces after the termination of their use.

Less represented in the monitored territory are the step balks (Fig. 10) occurring mainly in the areas with milder slopes and they are characteristic especially for localities with higher representation of plots with quadrangle shape.

The areas cultivated on the slopes are generally larger than those in the case of typical terraces. The field margins separating each area are shorter, lower (usually only up to $0.5 \mathrm{~m}$ ) and narrower (up to $1 \mathrm{~m}$ ). At these balks, the representation of trees is significantly lower than that in the case of balks on the terraces and they are dominated by grassy vegetation. As these low balks now largely separate areas used as PGS and no new rocky material is deposited into them, they are usually mowed on regular basis along with the surrounding meadows.

In the lowest parts of the slopes with the smallest inclination, these

low balks have the character of low sandy loam-rocky mounds, which are, for example, in the case of plots with quadrangle shape, often vertically (in the direction along the fall line) followed by low mounds or mound-like forms created between individual plots or along field paths and roads.

Quite common forms in the area are also heaps (Fig. 11), commonly called 'hromadnice', although their incidence in the monitored territory is very uneven. They can be found throughout the whole territory, but the highest incidence of heaps is in the cadastral area of Zákopčie village, where they were formed within the field margins or separately on the surfaces of larger plots and in the areas of Zborov nad Bystricou village and Oščadnica village, where these heaps are almost exclusively part of field margins. They are of different sizes and heights, and in terms of skeleton characteristic, the most widespread are rocky heaps and rocky-clay heaps. The heaps are characteristic for their distinctive vegetation, which dif- 
fers from the surrounding vegetation in species composition, whether they are located on the plots or on the surrounding balks. Less represented are grasses and meadow plants, and most dominant are nitrophilous species and species that are able to withstand the drying of substrate, respectively those rooted at greater depths (because rocky heaps have the character of overgrown scree). A characteristic feature of nearly all heaps in the territory is that in addition to the various species of bushes, they are covered by tree plants too, often by the biggest individual trees in the area (as part of the vegetation categorised as NFWV).

\section{Vegetation of forms of anthropogenic relief}

From the monitored territory of various FAR, 128 phytosociological relevés were obtained, assessed, compared with the data obtained from surrounding biotopes and tested on their possible relation to some of the biotopes of European or national significance (Ružičková et al., 1996; Stanová, Valachovič, 2002) in relation to possible proposals on legislative protection of TAL, or of biodiversity in individual FAR.

Based on the comparison from all types of FAR from Kysuce region, it can be stated that the variability of vegetation is not as high as was previously supposed. It is connected with the character of natural conditions of the region and also with the state of utilisation of TAL areas, where the majority of these areas (almost about 90\%) are PGS (Fig. 12) and only occasionally it is arable land. At the same time it has to be stated that a great part of these locations is not utilized in the present any more.

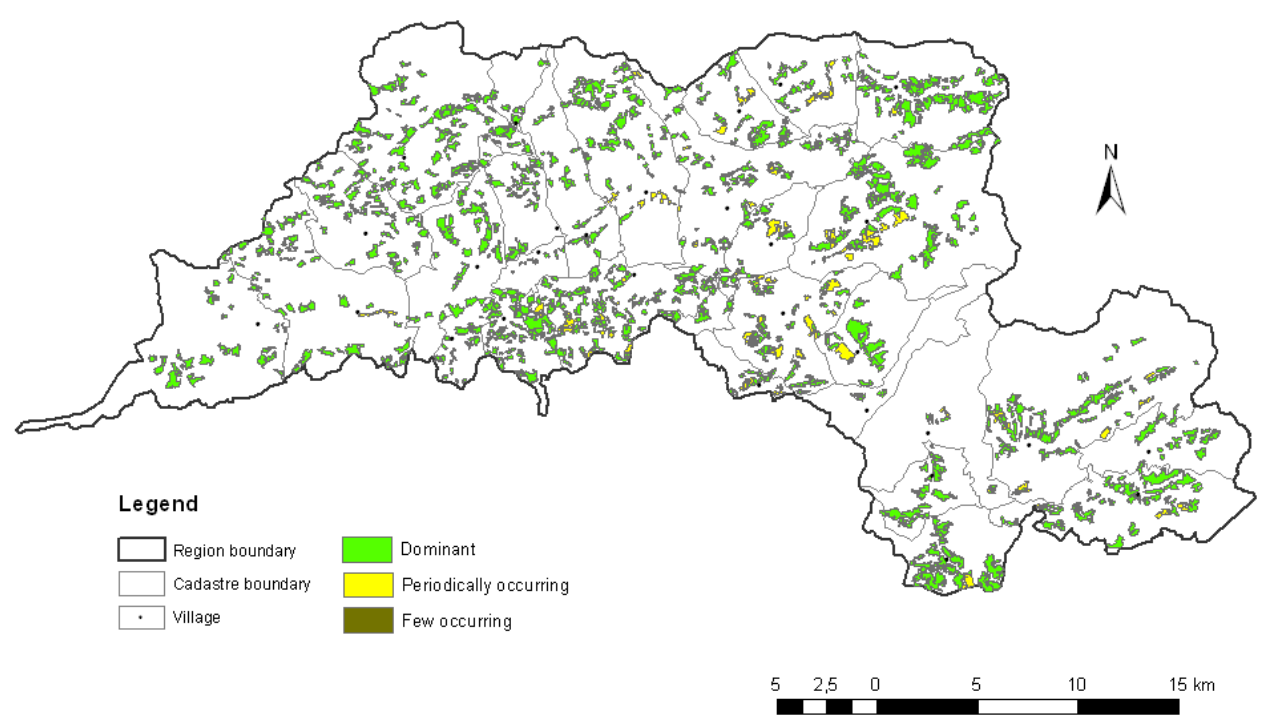

Fig. 12. Representation of grassy vegetation in the areas of TAL in Kysuce region. 


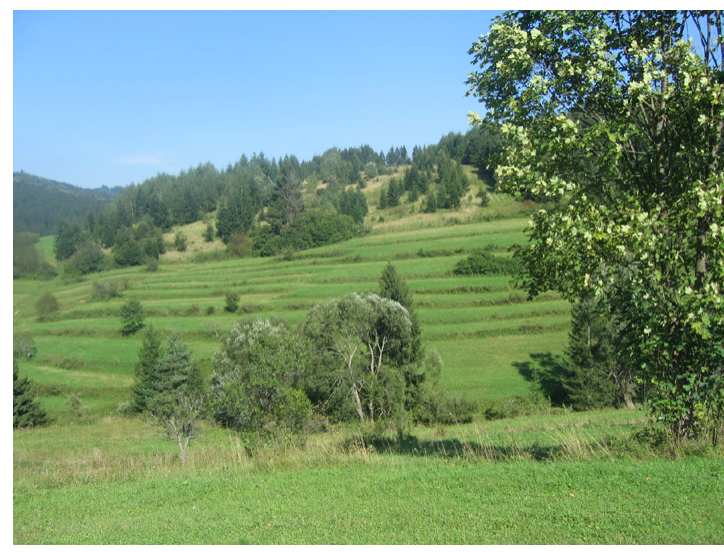

Fig. 13. Terraces with PGS and mown balks (Lutiše village).

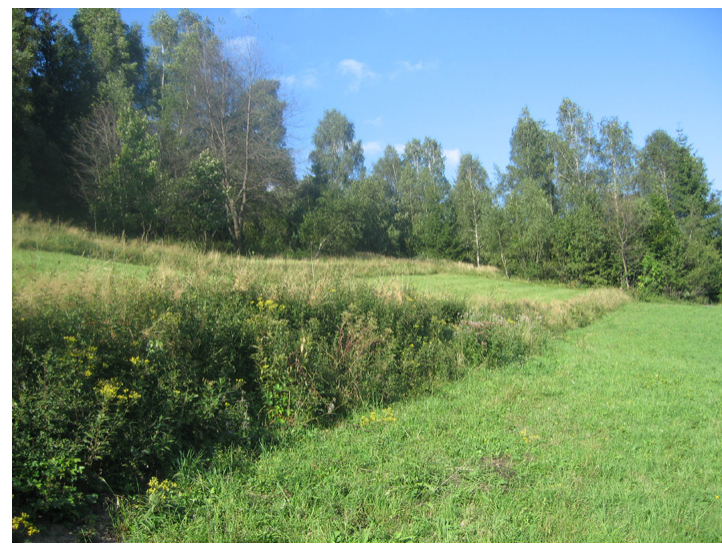

Fig. 14. Terraces with PGS and mainly not mown balks (Čadca town).

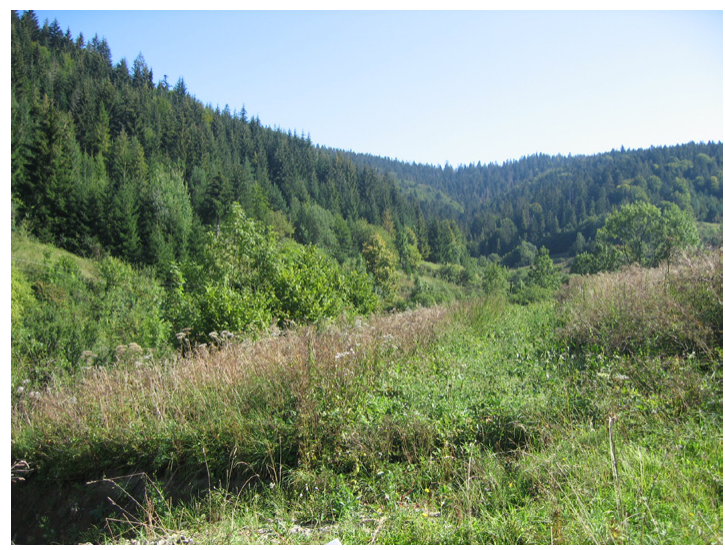

Fig. 15. Terraces with arable land and nitrophilous vegetation on balks (Radôstka village).
On TAL locations where plots are used as PGS (mostly as meadows), species composition of the balks vegetations is the same or very close to the species composition of grassland stands on terraces or surrounding slopes (Figs 13 and 14). On the whole monitored region communities of mesophilous meadows, Arrhenatherion elatioris Koch 1926 are dominant - the most common associations are Poo-Trisetetum Knapp ex Oberd. 1957 (recorded on almost whole region), Anthoxantho odoratiAgrostietum tenuis Sillinger 1933 (recorded on almost whole region), and Pastinaco sativae-Arrhenatheretum elatioris Passarge 1964 (e.g. Lutiše village). Less represented are communities of the association Lolio perennis-Cynosuretum cristati $\mathrm{R}$. Tx. 1937 (e.g. Zákopčie, Nová Bystrica villages).

In the lower elevations on humid shallow slopes and on margins of flood plains of watercourses communities of humid meadows from alliance Calthion palustris Tüxen 1937 - populations of associations Cirsietum rivularis Nowiński 1927 interfere into TAL areas (Skalité, Čierne, Nová Bystrica, Vysoká nad Kysucou, Korňa, Klokočov villages and also elsewhere). Less common is also Angelico sylvestris-Cirsietum palustris Darimont ex BalátováTuláčková 1973 interfere into TAL areas (Klokočov village).

On terrace balks, which are used as arable land, are grassland stands similar to those on PGS but only when mown regularly, and nowadays, material from terraces (rocks, 
weeded plants, dung, etc.) is not deposited there. However, more often there are nitrophilous species, as nutrients from terraces seep there. Grassy terraces and regular mowing do not allow nitrophilous species to gain dominance and their typical communities to evolve here.

Nitrophilous ruderalised vegetation (Fig. 15) evolves at the balks if the terraces are regularly used as arable land, are almost never mown (or are mown only sporadically) and a regular supply of nutrients is provided (especially nitrogen from fertilising biological waste weeded during cultivation). Syntaxonomically, these populations belong mainly to class Galio-Urticetea Passarge ex Kopecký 1969 and less to class Artemisietea vulgaris Lohmeyer et al. in R. Tx. ex von Rochow 1951.

Representation of NFWV in the region is quite high, and all types of NFWV can be documented here, from solitaire to continuous wood growths (Figs 16-18). However, in the majority of the cases, they cannot be specifically categorised into some vegetation unit.

The vegetation of monitored FAR does not consist of area-specific plant communities, but it is made of species of several types of vegetation.

The most characteristic are the communities that belong to biotope Tr8 Species-rich Nardus grasslands on siliceous substrates that could be included within the Nardo-Agrostion tenuis family Sillinger 1933. They were recorded only in isolated small areas on very small balks or on mounds that nowadays blend into

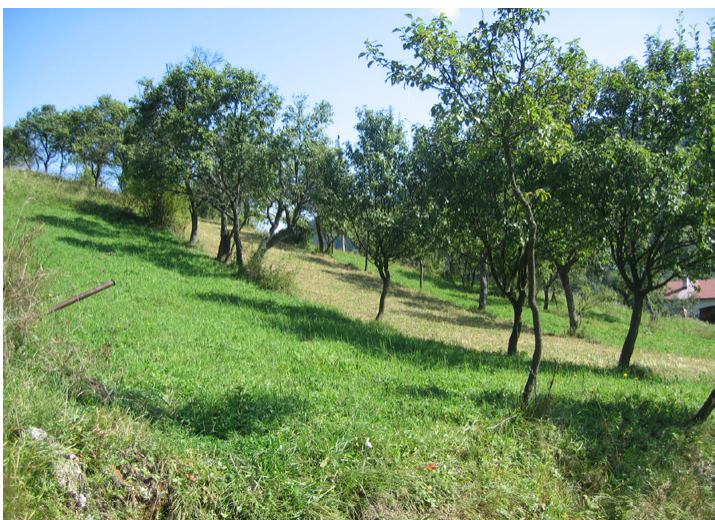

Fig. 16. Terraces with PGS or arable land and orchard trees on balks (Radôstka village).

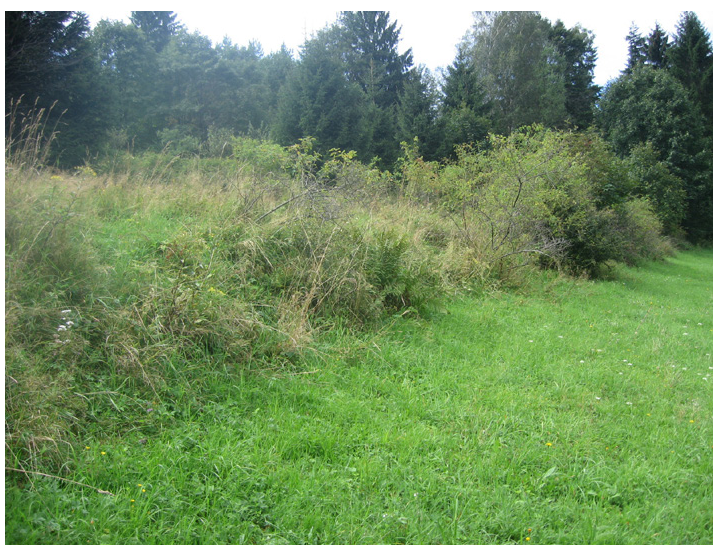

Fig. 17. Shrubbery balks (Zákopčie village).

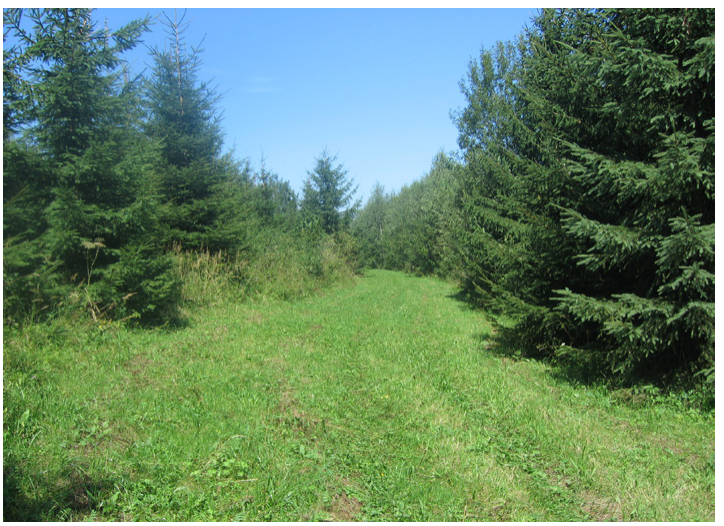

Fig. 18. Utilized terraces with PGS with continuous stand of woods on balks similar to forest (Lutiše village). 
the surrounding vegetation on parcels and represent former pastures on which cattle is sporadically tended even today. These communities belong to the poorest as to the species on the monitored region. The species such as Avenella flexuosa, Nardus stricta, Calluna vulgaris, Luzula campestris, Potentilla erecta, Anthoxanthum odoratum, Cruciata glabra, Hieracium lachenalii, Vaccinium myrtillus and Veronica officinalis have been recorded here.

The most spread communities are growths that were classified to biotope Lk1 Hay meadows that can be characterised as communities of the Arrhenatherion elatioris family Koch 1926. As to species they are very rich, containing not only the characteristic species of communities of the above mentioned family but also species of nitrophilous ruderal vegetation that profit from the specific conditions of the FAR. Species such as Arrhenatherum elatius, Dactylis glomerata, Campanula patula, Leontodon hispidus, Leucanthemum vulgare, Trifolium pratense, Agrostis capillaris, Acetosa pratensis, Achillea millefolium, Festuca pratensis and F. rubra have been recorded here. Species variability of these communities as well as the location variability (they are on almost all FAR) is large, and even though this type of vegetation has the majority of records, another field study is needed for their detailed differentiation and classification. These communities are influenced the most by overgrowing wood vegetation.

Shrubs that gradually grow into continuous growths were classified as biotope Kr7 blackthorn and hazel scrubs. Their occurrence is limited to larger balks or unused terraces and form communities belonging to the Berberidion vulgaris Br.-Bl. 1950 and Corylo-Populion tremulae families Br.-Bl. 1961 depending on the representation of individual species of shrubs and accompanying grasses and herbs in the undergrowth. There are mainly Prunus spinosa, Rosa canina, Corylus avellana, Crataegus monogyna, Padus avium, Rubus fruticosus agg., Sambucus nigra, Viburnum opulus, Crataegus laevigata, Frangula alnus, Rosa tomentosa, Sambucus racemosa and so on.

In lower parts of slopes on damp or wet locations on FAR, we can find growths that were classified into biotope Lk6 Waterlogged meadows mountain and foothill areas which belong to communities of the Calthion palustris family R. Tx. 1937. The occurrence of the characteristic species is conditioned by water that enables good differentiation of these communities (Alopecurus pratensis, Caltha palustris, Filipendula ulmaria, Lysimachia vulgaris, Myosotis scorpioides, Cirsium rivulare, Deschampsia cespitosa, Holcus lanatus, Lychnis flos-cuculi, Ranunculus repens, Lathyrus pratensis, etc.). Species of ruderal vegetation pervade into these communities as well, and thus the communities have species composition different from the typical communities belonging to the given family. Species spectrum and water regime of the areas is influenced by degree and character of usage of the plots as well. Intensively used surfaces do not have enough water to sustain the community and thus nitrophilous species of ruderal vegetation become dominant here.

On the monitored region, vegetation which was classified as belonging to biotope X3 Nitrophilous ruderal vegetation out of settlements (e.g. Aegopodium podagraria, Urtica dioica, Anthriscus sylvestris, Elytrigia repens, Cirsium arvense, Poa trivialis, Rumex obtusifolius) is highly represented on FAR. Nowadays, we can state that with regards to their species composition and representation of some diagnostic species, communities forming mostly on balks will belong to the Aegopodium podagrariae family R. Tx. 1967 and Carduo-Urticion dioicae Hadač ex Hadač et al. 1969. 
Rock heaps and mounds whose vegetation we provisionally classified to biotope Sk7 Secondary debris and rocky habitats has a special position with regards to vegetation. In the majority of cases, they contain little soil and their whole internal structure is influenced by the number and size of rocks deposited on them and by the amount of organic material that is deposited in them together with the rocks. Older heaps with more soil are often covered in continuous vegetation that is closer to ruderal vegetation, as to its species representation, than to the vegetation of meadows/grasslands (or ruderalised meadows). We can find there almost always woods and nowadays even adult individual trees (e.g., in Oščadnica, Zákopčie, Vreščovka villages and others), where the grass growth is permanently in shadow and thus these communities lack the light-demanding Meadow species. On younger heaps with little soil, the wood vegetation is represented less and with regards to rocky permeable substrate, mainly light-demanding and xerophilous species of ruderal vegetation, take root here.

\section{Conclusion}

The Kysuce region, with its well-preserved areas with TAL, is extensive, and we can safely say that it is one of the largest in Slovakia. TAL is the outstanding feature of colonisation and settlement of rural landscapes. Deforestation of the landscape and its gradual transformation into an agricultural landscape by human activity left behind traces. Historical changes in this country go hand in hand with changes in area occurrence and variability of vegetation species and their communities. In the past 20 years, a general trend of development of the area is visible, significant part of TAL ceases to be used in traditional agriculture on narrow terraced plots and it is no longer regularly mown or cattle is no longer tended on terraced and mountain meadows. As a result, arable land is transformed into wasteland, meadows and pastures are overgrown by woody vegetation and original biotopes change their species composition. Mainly, the original meadows rich in species gradually change into monotonous meadow wastelands with only a few dominant vegetation species, proportion of wood vegetation increases and their original species diversity is lost. Some types of mountain meadow communities, mesophilous pastures and tended meadows and damp or wet meadows whose existence is dependent on their agricultural usage are gradually lost. Forms of anthropogenic relief have been created during the cultivation of agricultural landscape and represent an island of biodiversity. The configuration of landscape structures is changing, and there is a risk of the slow loss of its originality and uniqueness.

The maintenance of TAL is dependent on human activity. We have to seriously consider and look for new ways to preserve them for the next generation.

\section{Acknowledgements}

\footnotetext{
The contribution was prepared within the grant project of the Ministry of Education of the Slovak Republic and the Slovak Academy of Sciences No. 2/0078/15 'Ecological optimization of the utilization of landslide areas in selected parts of the flysch zone in regard to the traditional farming'.
}

\section{References}

Baran-Zgłobicka, B. \& Zgłobicki W. (2012). Mosaic landscapes of SE Poland: should we preserve them? Agrofor. Syst., 85, 351-365. DOI: 10.1007/s10457-011-9436-x 
Barančok, P. \& Barančoková M. (2016). Types of traditional agricultural landscapes and their respective representation in the Kysuce region. In L. Halada, A. Bača \& M. Boltižiar (Eds.), Landscape and landscape ecology (pp. 45-26). Bratislava: Institute of Landscape Ecology SAS.

Bezák, P. \& Mitchley J. (2014). Drivers of change in mountain farming in Slovakia: from socialist collectivisation to the common agricultural policy. Regional Environmental Change, 14, 1343-1356. DOI: 10.1007/s10113-0130580-x.

ČÚGK \& SÚGK (1980). Statistical yearbook of the land resources in Czechoslovakia, according to the data register of immovable property (in Slovak). Praha: Český úřad geodetický a kartografický, Slovenský úrad geodézie a kartografie. http://datacube.statistics.sk/TM1WebSK/TM1WebLogin.aspx

Demo, M. et al. (2001). History of agriculture in Slovakia (in Slovak). Nitra: SPU.

Dobrovodská, M., Špulerová, J., Štefunková, D. \& Halabuk, A. (2010). Research and maintenance of biodiversity in historical structures in the agricultural landscape of Slovakia. In M. Barančoková, J. Krajčí, J. Kollár \& I. Belčáková (Eds.), Landscape ecology - methods, applications and interdisciplinary approach (pp. 131-140). Bratislava: Institute of Landscape Ecology, SAS.

Izakovičová, Z., Moyzeová, M., Bezák, P., Dobrovodská, M., Grotkovská, L., Hrnčiarová, T., Kenderessy, P., Krnáčová, Z., Majerčák, J., Miklošovičová, Z., Moyses, M., Pavličková, K., Petrovič, F., Špulerová, J., Štefunková, D. \& Válkovcová Z. (2008). Assessment of agricultural landscape in transitional economy (in Slovak). Bratislava: UKE SAV.

Kanianska, R., Kizeková, M., Nováček, J. \& Zeman M. (2014). Landuse and land-cover changes in rural areas during different political systems: a case study of Slovakia from 1782 to 2006. Land Use Policy, 36, 554-566. DOI: 10.1016/j.landusepol.2013.09.018.

Kristiánová, K. \& Adamková J. (2010). Slovak agricultural landscape-transition responses. ITU Journal of the Faculty of Architecture, 7(2), 121-132.Lipský, Z. (1995). The changing face of the Czech rural landscape. Landsc. Urban Plann., 31(1-3), 39-45. DOI:10.1016/0169-2046(94)01034-6.

MacDonald, D., Crabtree, J.R., Wiesinger, G., Dax, T., Stamou, N., Fleury, P., Gutierrez-Lazpita, J. \& Gibon A.Q. (2000). Agricultural abandonment in mountain areas of Europe: environmental consequences and policy response. J. Environ. Manag., 59, 47-69. DOI:10.1006/jema.1999.0335.

Miklós, L. (2002). Natural - settlement nodal regions (in Slovak). In Atlas krajiny SR (pp. 206-207). Bratislava: MŽP SR, Banská Bystrica: SAŽP.

Mitchley, J., Price, M. \& Tzanopoulos J. (2006). Integrated futures for Europe’s mountain regions: reconciling biodiversity conservation and human livelihoods. Journal of Mountain Science, 3, 276-286. DOI: 10.1007/s11629006-0276-5.

Morell, I.A. (2012). Collectivization and the transfer of soft capital in two life stories from Hungary. Ager : Revista de Estudios Sobre Despoblacio'n y Desarrollo Rural, 13, 125-153. DOI: 10.4422/ager.2012.08.

Olschofsky, K., Kohler, P., Gerard, F., Thomson, A., Manchester, S., Smith, G., Wadsworth, R., Swetnam, R., Petit, S., Gregor, M., Sandra, L., Huitu, H., Hazeu, G., Mucher, S., Halada, L., Bugar, G. \& Pino J. (2006). Land cover change in Europe from the 1950'ies to 2000. Aerial photo interpretation and derived statistics from 59 samples distributed across Europe. Hamburg: Institute of World Forestry.

Palang, H. (2010). Time boundaries and landscape change: collective farms 1947-1994. European Countryside, 2 , 169-181. DOI: 10.2478/v10091-010-0012-6.

Petrovič, F. (2006). The changes of the landscape with dispersed settlement. Ekológia (Bratislava), 25(1), 65-89.

Plieninger, T., Höchtl, F. \& Spek T. (2006). Traditional land-use and nature conservation in European rural landscapes. Environmental Science and Policy, 9, 317-321. DOI: 10.1016/j.envsci.2006.03.001.

Price, M.F. (Ed.) (2006). Global change in mountain regions. Duncow: Sapiens Publishing.

Reed, M.S., Arblaster, K., Bullock, C., Burton, R., Davies, A.L., Holden, J., Hubacek, K., May, R., Mitchley, J., Morris, J., Nainggolan, D., Potter, C., Quinn, CH., Swales, V. \& Thorp S. (2009). Using scenarios to explore UK upland futures. Futures, 41, 619-630. DOI: 10.1016/j.envsci.2006.03.001.

Ružičková, H., Halada, L., Jedlička, L. \& Kalivodová E. et al. (1996). Habitats in Slovakia (in Slovak). Bratislava: ÚKE SAV.

Sitár, E. (1967). Dispersed settlement in the Slovakia (some questions about present time) (in Slovak). Vlastivedný Časopis, 16(3), 125-135.

Spehn, E.M., Liberman, M. \& Körner Ch. (Eds.) (2006). Land use change and mountain biodiversity. Boca Raton: CRC Press/Taylor and Francis.

Swinnen, J.F. (1999). The political economy of land reform choices in Central and Eastern Europe. Economics of Transition, 7, 637-664. DOI: 10.1111/1468-0351.00029. 
Stanová, V. \& Valachovič M. (Eds.) (2002). List of habitats in Slovakia (in Slovak). Bratislava: DAPHNE - Inštitút aplikovanej ekológie.

Špulerová, J., Dobrovodská, M., Lieskovský, J., Bača, A., Halabuk, A., Kohút, F., Mojses, M., Kenderessy, P., Piscová, V., Barančok, P., Gerhátová, K., Krajčí, J. \& Boltižiar M. (2011). Inventory and classification of historical structures of the agricultural landscape in Slovakia. Ekológia (Bratislava), 30(2), 157-170. DOI: 10.4149/ekol _2011_02_157.

Špulerová, J., Dobrovodská, M., Štefunková, D., Piscová, V. \& Petrovič F. (2014). Evolution of the traditional agricultural landscapes of Slovakia. In R. Efe \& M. Ozturk (Eds.), Environment and ecology in the Mediterranean region II (pp. 133-145). Newcastle: Cambridge Scholars Publishing.

Tóthová Z., Sabo P. \& Čárska H. (Eds.), (Bevilaqua D., Čárska H., Darnady A., Derka T., Galvánek J., Gerát R., Hudek V., Korňan J., Kuderavá Z., Matejová M., Pietorová E., Sabo P., Šulgan M., Tóthová Z., Urbanová V., Vrábel J.) (1996). Kysuce region nature protection and cooperation on the sustainable development (in Slovak). Published by the IUCN Foundation, World Union of Nature Protection, Slovakia, Bratislava, Cambridge, United Kingdom and Gland, Switzerland.

Turnock, D. (2002). Ecoregion-based conservation in the Carpathians and the land-use implications. Land Use Policy, 19, 47-63. DOI: 10.1016/S0264-8377(01)00039-4.

Young, J., Richards, C., Fischer, A., Halada, L., Kull, T., Kuzniar, A., Tartes, U., Uzunov, Y. \& Watt A. (2007). Conflicts between biodiversity conservation and human activities in the central and eastern European countries. Ambio, 36, 545-550. DOI: 10.1579/0044-7447(2007)36[545:CBBCAH]2.0.CO;2. 